E-ISSN : 2549-6581

DOI: 10.21776/ub.JOIM.2020.004.02.3

Artikel Hasil Penelitian

Diterima : 1 Juni 2019

Direview : 24 April 2020

Dimuat : Agustus - November 2020
OPEN ACCESS

Journal of Issues in Midwifer

\title{
Pengaruh Pemberian Ekstrak Etanol Brokoli (Brassica oleracea) terhadap Kadar Superoxide Dismutase (SOD) Ovarium Tikus Putih (Rattus norvegicus) Galur Wistar yang Dipapar Monosodium Glutamat (MSG)
}

\author{
Novi Dwi Palupi ${ }^{1 *)}$, Nurdiana ${ }^{2}$, Nur Aini Retno Hastuti ${ }^{3}$ \\ 1*) Program Studi S1-Kebidanan, Fakultas Kedokteran, Universitas Brawijaya, \\ Email: palupinovi54@gmail.com \\ ${ }^{2}$ Departemen Farmakologi, Fakultas Kedokteran, Universitas Brawijaya \\ ${ }^{3}$ Program Studi S1-Kebidanan, Fakultas Kedokteran, Universitas Brawijaya
}

\begin{abstract}
Excessive consumption of MSG will stimulate free radicals. Basically in the body there is a mechanism of self-protection from free radicals using endogenous antioxidants, one of which is Superoxide dismutase (SOD). However, if the levels of free radicals with unbalanced antioxidant levels will cause oxidative stress which can interfere with the function of ovarian organs. So, the body needs exogenous antioxidants, on of which is broccoli (Brassica oleracea). Broccoli contains flavonoid which will stabilize free radicals. The purpose of this study was to research the effect of giving broccoli ethanol extract for increase ovarian SOD levels in rats exposed MSG. The study used post test only control group design for 35 days (7 days of adaptation and 28 preparations) with sample of 30 rats and divided into 5 groups, that is a K-without esposure MSG and broccoli ethanol extract, $K+$ exposed MSG 0,7 mg/gBB without broccoli ethanol extract dan P1, P2, P3 exposed MSG 0,7 mg/gBB and broccoli ethanol extract $500 \mathrm{mg} / \mathrm{KgBB}, 1000 \mathrm{mg} / \mathrm{KgBB}$, and $2000 \mathrm{mg} / \mathrm{KgBB}$. Day 29 rat in the proestrus phase will surgery. Measurement of SOD levels using a spectrophotometer. Data analysus ANOVA, Tukey's Post Hoc, and Spearman rank. The results showed $\rho<0,05$ that there was an effect of giving broccoli ethanol extract to increase in ovarian SOD levels, SOD levels of group P1, P2, P3 increased significantly compared to the negative control group. This study concluded that broccoli ethanol extract can increase ovarian SOD levels in rats exposed MSG.
\end{abstract}

Keywords: Monosodium Glutamate, Broccoli, Superoxide Dismutase, Free radicals

\section{ABSTRAK}

Konsumsi monosodium glutamat (MSG) berlebihan akan menstimulasi pembentukan radikal bebas. Pada dasarnya dalam tubuh terdapat mekanisme perlindungan diri dari radikal bebas menggunakan antioksidan endogen, salah satunya Superoxide dismutase (SOD). Namun, apabila kadar radikal bebas dengan kadar antioksidan tidak seimbang akan menyebabkan terjadinya stres oksidatif yang dapat mengganggu fungsi organ ovarium. Sehingga, tubuh memerlukan antioksidan eksogen, salah satunya adalah brokoli (Brassica oleracea). Brokoli mengandung senyawa flavonoid yang akan menstabilkan radikal bebas. Tujuan penelitian ini adalah untuk mengetahui pengaruh pemberian ekstrak etanol brokoli terhadap peningkatan kadar SOD ovarium tikus putih yang dipapar MSG. Penelitian ini menggunakan rancangan post test only control group design selama 35 hari (7 hari adaptasi dan 28 perlakuan) dengan sampel 
sebanyak 30 tikus dan dibagi menjadi 5 kelompok, yaitu K- tanpa paparan MSG dan ekstrak etanol brokoli, $\mathrm{K}+$ dipapar MSG 0,7 mg/gBB tanpa ekstrak etanol brokoli dan P1, P2 dan P3 dipapar MSG 0,7 mg/gBB dan ekstrak etanol brokoli $500 \mathrm{mg} / \mathrm{KgBB}, 1000$ $\mathrm{mg} / \mathrm{KgBB}$ dan $2000 \mathrm{mg} / \mathrm{KgBB}$. Pada hari ke-29 dilakukan terminasi pada tikus yang mengalami fase proestrus. Pengukuran kadar SOD menggunakan spektofotometer. Analisis data menggunakan ANOVA, Post Hoc Tukey, dan Spearman rank. Hasil penelitian menunjukan $\rho<0,05$ sehingga terdapat pengaruh pemberian ekstrak etanol brokoli terhadap peningkatan kadar SOD ovarium, kadar SOD kelompok P1, P2, dan P3 meningkat secara signifikan dibandingkan dengan kelompok kontrol negatif, serta dosis efektif pemberian ekstrak etanol brokoli yang mampu meningkatkan kadar SOD ovarium adalah dosis $2000 \mathrm{mg} / \mathrm{KgBB}$. Dapat disimpulkan bahwa ekstrak etanol brokoli dapat meningkatkan kadar SOD ovarium tikus putih yang dipapar MSG.

Kata kunci: Monosodium Glutamat, Brokoli, Superoxida Dismutase, Radikal bebas

`Korespondensi: Palupi Dwi Novi. Surel: palupinovi54@gmail.com

\section{PENDAHULUAN}

Pada tahun 2015 pertumbuhan industri makanan dan minuman berkembang sangat pesat. Pertumbuhan ini mengakibatkan konsumsi masyarakat semakin beragam. Masyarakat cenderung lebih memilih makanan cepat saji yang identik dengan kandungan penyedap rasa, yaitu monosodium glutamat $^{(1)}$.

Konsumsi MSG $30 \mathrm{mg} / \mathrm{kgBB} /$ hari dapat meningkatkan kadar glutamat dalam plasma(2). Peningkatan glutamat menyebabkan stimulasi pada reseptor glutamat $\mathrm{N}$-methyl-DAspartate (NMDA) yang memiliki kemampuan untuk meningkatkan kadar $\mathrm{Ca}^{2+}$ dalam mitokondria. Peningkatan $\mathrm{Ca}^{2+}$ akan menstimulasi pembentukan nitrit oxide yang merupakan radikal bebas $^{(3,4)}$. Terdapat penelitian menyebutkan bahwa konsumsi MSG dengan dosis $4 \mathrm{mg} / \mathrm{gBB}$ pada tikus dapat menyebabkan penurunan kadar glutathione dan superoxide dismutase (SOD) yang berfungsi sebagai perlindungan tubuh terhadap radikal bebas $\left({ }^{5,6}\right)$.

Radikal bebas akan merusak protein, sel, jaringan dan organ pada tubuh $^{(7)}$. Salah satu gangguan pada organ tubuh adalah gangguan pada organ ovarium yang dapat mempengaruhi fertilitas. Terdapat penelitian menyebutkan bahwa pemberian MSG dengan dosis berlebihan akan menghasilkan radikal bebas yang dapat menyebabkan penurunan jumlah folikel dan beberapa kerusakan pada sel-sel di dalam ovarium $^{(8)}$. Kerusakan pada ovarium akibat radikal bebas berdampak buruk bagi kesehatan reproduksi, sehingga dibutuhkan antioksidan untuk menangkal radikal bebas dari $\mathrm{MSG}^{(9)}$.

Antioksidan endogen berfungsi sebagai antioksidan alami dalam tubuh. Namun, jika kadar radikal bebas dalam tubuh berlebihan maka aktioksidan yang berfungsi untuk memeranginya tidak seimbang. Oleh sebab itu tubuh memerlukan antioksidan dari luar untuk menangkal peningkatan radikal bebas.

Salah satu sumber antioksidan eksogen yang memiliki aktivitas antioksidan tinggi yaitu brokoli (Brassica olaracea). Brokoli mengandung air, protein, lemak, 
karbohidrat, serat, kalsium, zat besi, vitamin ( $A, C, E$,), beta karoten, dan glutathione ${ }^{(10)}$. Brokoli mengandung senyawa fenolik yaitu flavonoid dalam jumlah yang tinggi. Senyawa flavonoid yang terkandung dalam brokoli adalah asam hidroksinan, glikosinolat, polifenol, dan sulforafan $^{(9)}$. Kandungan flavonoid pada brokoli akan menyumbangkan satu atom hidrogennya untuk menstabilkan radikal bebas ${ }^{(11)}$.

Melihat potensi brokoli sebagai antioksidan dalam meningkatkan SOD maka perlu dilakukan pembuktian mengenai efek ektrak etanol brokoli terhadap peningkatan kadar SOD ovarium tikus putih yang dipapar monosodium glutamat.

\section{METODE PENELITIAN}

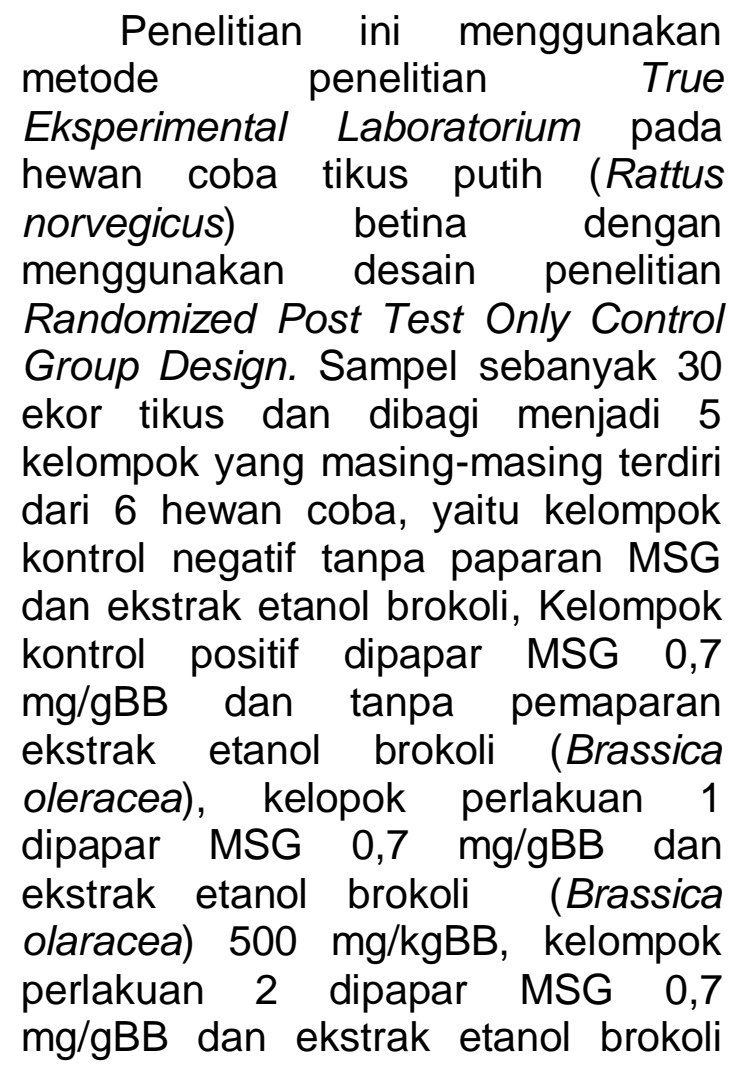

(Brassica olaracea) 1000 mg/kgBB dan kelompok perlakuan 3 dipapar MSG 0,7 mg/gBB dan ekstrak etanol brokoli (Brassica olaracea) 2000 $\mathrm{mg} / \mathrm{kgBB}$. Proses adaptasi hewan coba dilakukan selama 7 hari dilanjut dengan perlakuan selama 28 hari.

Pemberian larutan MSG dan ekstrak etanol brokoli (Brassica oleracea) sesuai dengan dosis secara per oral dengan menggunakan sonde. Pada hari ke29 dilakukan swab vagina untuk mengetahui fase proestrus tikus. Tikus yang dalam masa pro estrus dilakukan pembedahan dan diambil ovarium kiri kemudian dilakukan penghitungan kadar SOD dengan spektofotometer.

\section{HASIL PENELITIAN}

Hasil kadar SOD dianalisis menggunakan uji One-Way ANOVA dengan syarat sebaran data normal dan varian data sama. Selanjutnya dilanjutkan dengan uji post Hoc Tukey, dan untuk mengetahui kekuatan hubungan antara pemberian ekstrak etanol brokoli (Brassica oleracea) dengan kadar SOD ovarium maka dilakukan uji Spearman rank.

\section{Uji Shapiro Wilk}

Berdasarkan uji normalitas, kadar SOD memiliki nilai $p=0,155$ sehingga menunjukkan bahwa distribusi data normal ( $p>0,05)$.

\section{Uji Homogenitas}

Berdasarkan uji homogenitas, kadar SOD memiliki $\rho=0.206$. Sehingga, menunjukan bahwa data memiliki varians homogen $\rho>0.05$. 


\section{Gambar 1 Rerata kadar SOD dan Standar Devisiasi Kadar SOD}

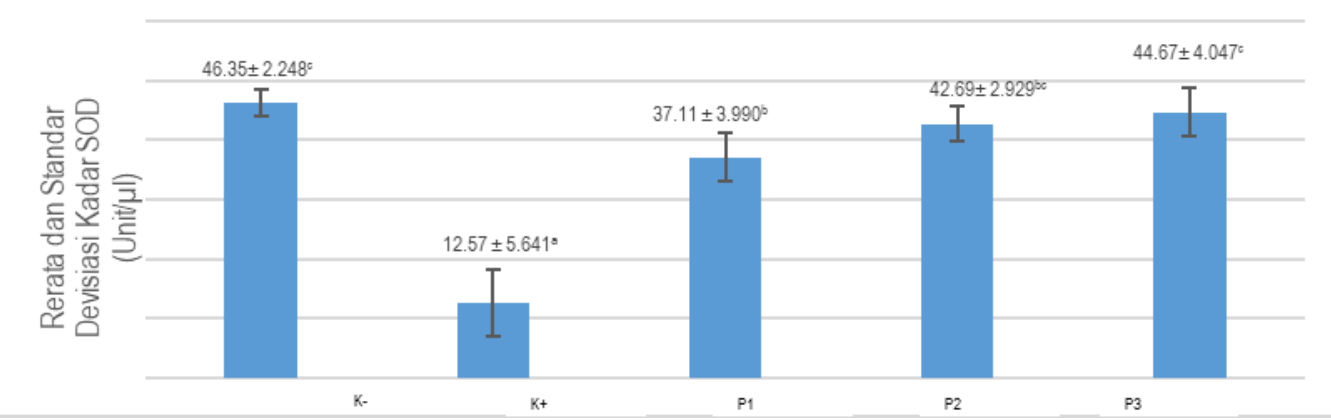

Pengukuran kadar SOD pada kelompok kontrol negatif (K-) memiliki rerata 46,35 Unit/ $\mu$ l. Hasil pengukuran kadar SOD pada kelompok $\mathrm{K}+$ memiliki rerata 12,56

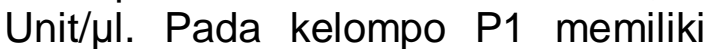

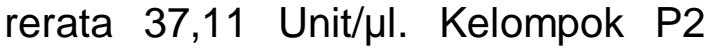
memiliki rerata 42,68 Unit/ $\mu$. Kelompok P3 memiliki rerata 44,66

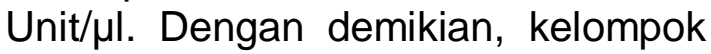
$\mathrm{K}^{+}$memiliki rerata kadar SOD paling rendah. Pada tikus yang dipapar ekstrak etanol brokoli (Brassica oleracea) dengan berbagai dosis menunjukan rerata kadar SOD lebih tinggi dibandingkan dengan kelompok kontrol positif. Hal ini menunjukan adanya peningkatan kadar SOD pada kelompok yang dipapar ekstrak etanol brokoli (Brassica oleracea) dengan berbagai dosis. Untuk melihat perbedaan kadar SOD signifikan atau tidak, dilakukan pengujian menggunakan ANOVA.

$$
\text { Uji One-Way }
$$

ANOVA didapatkan hasil $\rho<0,05$ yang dapat diartikan bahwa terdapat pengaruh pemberian ekstrak etanol brokoli (Brassica oleracea) terhadap peningkatan kadar superoxida dismutase (SOD) tikus yang dipapar MSG. Bila hasil ANOVA signifikan maka dilanjutkan dengan uji Post Hoc test.

\section{Tabel 1 Hasil Uji Post Hoc Kadar SOD Ovarium Tikus Putih Pada Berbagai Perlakuan}

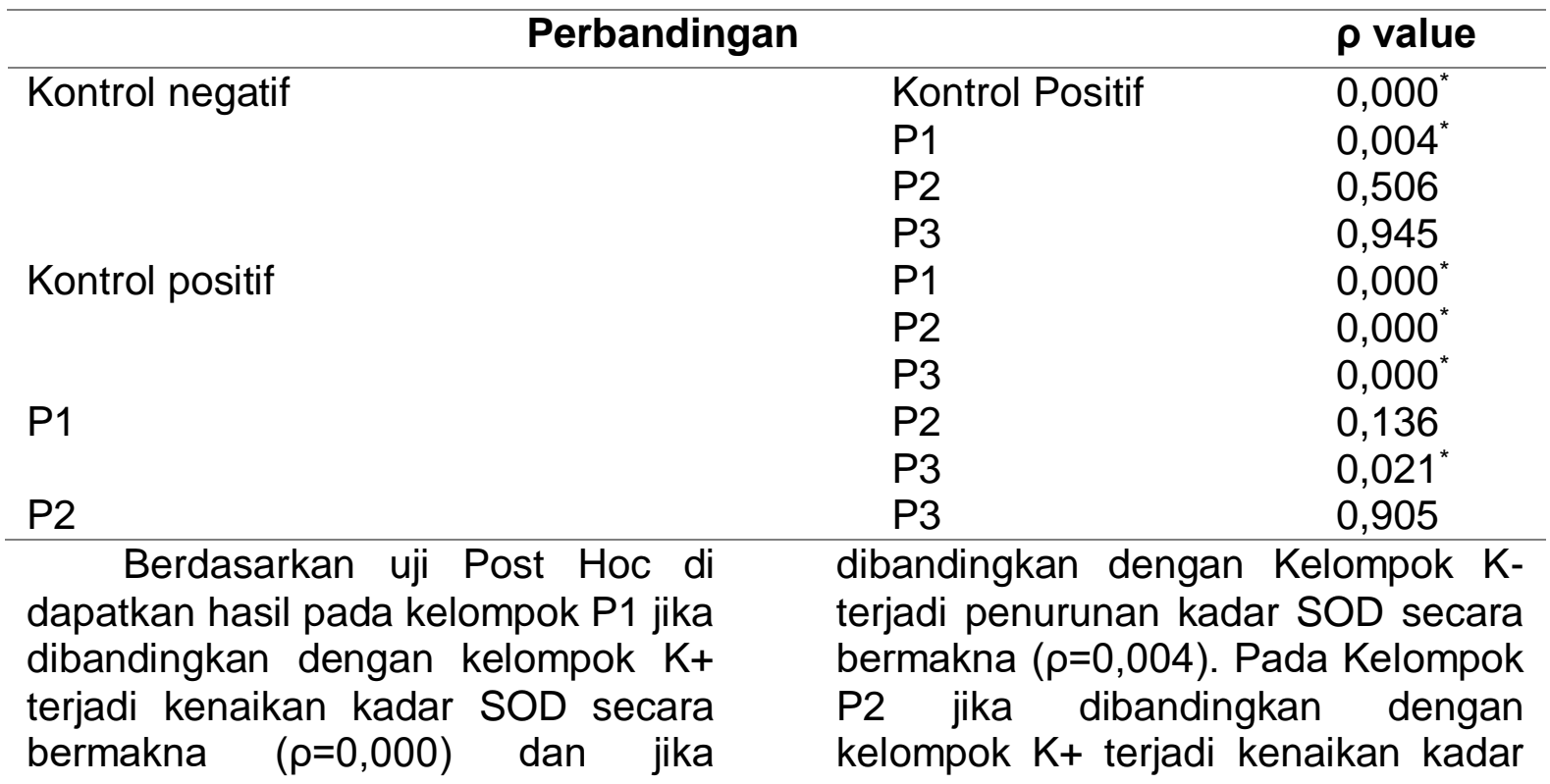


SOD secara bermakna $(\rho=0,000)$ dan jika dibandingkan dengan Kelompok $\mathrm{K}$ - terjadi penurunan kadar SOD secara tidak bermakna $(\rho=0,506)$. Pada Kelompok P3 jika dibandingkan dengan kelompok $\mathrm{K}+$ terjadi kenaikan kadar SOD secara bermakna $(\rho=0,000)$ dan jika dibandingkan dengan Kelompok K- terjadi penurunan kadar SOD secara tidak bermakna $(\rho=0,945)$.

Berdasarkan Uji Spearman rank didapatkan hasil $r=0,856$ yang berarti terdapat korelasi antara pemberian ekstrak etanol brokoli terhadap peningkatan kadar SOD. Sehingga, semakin tinggi dosis ekstrak etanol brokoli yang diberikan maka semakin tinggi kadar SOD.

\section{PEMBAHASAN}

Penelitian ini bertujuan untuk membuktikan pengaruh ekstrak etanol brokoli (Brassica oleracea) terhadap peningkatan kadar SOD (Superoxida dismutase) ovarium tikus putih (Rattus novercigus) yang dipapar MSG. Berdasarkan hasil penelitian, pengukuran kadar SOD pada kelompok kontrol negatif (K-) didapatkan rerata 46.35 Unit/ $\mu$ l. Keadaan ini merupakan kondisi normal pada tubuh ketika tidak terpapar radikal bebas secara berlebihan. Pada dasarnya radikal bebas memiliki fungsi fisiologis dan patologis dalam tubuh, salah satu fungsi fisiologisnya adalah berpengaruh pada beberapa aktifitas organ ovarium, yaitu pada saat perkembangan folikel dimana pada proses perkembangan folikel disertai dengan peningkatan fungsi metabolisme sel granulosa yang akan meningkatan aktivitas sitokrom $\mathrm{P}_{450}$ yang menstimulasi pembentukan radikal bebas dalam jumlah besar. Selain itu, proses ovulasi dikaitkan dengan reaksi peradangan yang membutuhkan radikal bebas sebagai modulator selama inflamasi pada proses rupturnya folikel(12). Pada kondisi tersebut, tubuh akan menangkal radikal bebas dengan menghasilkan antioksidan endogen, yaitu SOD. Diantara beberapa antioksidan, SOD merupakan antioksidan yang paling baik dalam memperbaiki kerusakan organ yang disebabkan oleh radikal bebas. ${ }^{13}$ SOD bekerja sebagai katalisator reaksi superoksida menjadi hidrogen peroksida dan oksigen ${ }^{(14)}$.

Hasil pengukuran kadar SOD pada kelompok kontrol positif $(\mathrm{K}+)$ didapatkan rerata 12,56 Unit/ $\mu$ l. Hasil tersebut merupakan rerata yang paling rendah dibandingkan dengan kelompok lain. Keadaan ini menggambarkan bahwa paparan MSG dapat menghambat aktivitas SOD ovarium. Hal ini disebabkan karena monosodium glutamat dapat menghasilkan radikal bebas yaitu dapat menginduksi terbentuknya radikal peroksida nitrit( ${ }^{15)}$. MSG juga dapat menyebabkan penurunan kadar SOD dalam tubuh(16). Penurunan kadar SOD menyebabkan terjadinya stres oksidatif yang berdampak pada kerusakan organ, hal ini terjadi karena radikal bebas akan bereaksi dengan protein, lipid dan DNA yang menimbulkan kerusakan sel dalam organ ${ }^{(17)}$. Salah satunya adalah organ ovarium. Pemberian MSG menyebabkan kerusakan struktur histologi ovarium, yaitu terlepasnya granulosa dari membran basal, terdapat banyak celah diantara sel-sel penyusun membran granulosa serta terlepasnya sel-sel folikel dan masuk ke antrum folikuli ${ }^{(18)}$. Selain itu, pemberian MSG juga menyebabkan terjadinya degenerasi sel granulosa, lapisan teka dan degenerasi ovum yang menyebabkan penurunan 
jumlah folikel sekunder dan folikel tersier $^{(7)}$. Hal ini merupakan suatu gangguan yang fatal sebab ovarium merupakan organ yang penting dalam sistem reproduksi yang berfungsi sebagai penghasil sel telur.

Pada kondisi radikal bebas melebihi jumlah antioksidan endogen maka akan menyebabkan kerusakan sel. Sehingga tubuh memerlukan antioksidan eksogen untuk mengimbanginya, salah satu sumber antioksidan eksogen yang mampu meningkatkan kadar SOD ovarium adalah Brokoli( ${ }^{(19)}$. Brokoli mengandung flavonoid yang merupakan sumber antioksidan eksogen. Mekanisme flavonoid sebagai antioksidan eksogen melalui tiga mekanisme, yaitu secara langsung mencegah kerusakan sel akibat radikal bebas, flavonoid mengandung quersetin yang dapat meminimalisir kerusakan akibat aktivitas nitrit oksidase sintetase dan flavonoid dapat menghambat aktifitas xantin oksidase yang merupakan jalur penting kerusakan oksidatif dalam jaringan ${ }^{(20)}$.

Pada kelompok P1 dengan dosis MSG 0,7 mg/gBB dan dosis ekstrak etanol brokoli $500 \mathrm{mg} / \mathrm{KgBB}$ tikus di dapatkan rerata 37,11 Unit/ $\mu$ l. Berdasarkan Uji Post Hoc jika dibandingkan kelompok P1 dengan kelompok $\mathrm{K}+$ terjadi kenaikan kadar SOD secara bermakna $(\rho=0,000)$ dan jika dibandingkan dengan kelompok $\mathrm{K}$ - maka terjadi penurunan kadar SOD secara bermakna $(\rho=0,004)$. Hal ini menunjukan bahwa dosis 500 $\mathrm{mg} / \mathrm{KgBB}$ belum mampu mengembalikan pada kondisi normal, hal ini kemungkinan disebabkan oleh kandungan antioksidan dari dosis yang diberikan masih belum mampu menetralisir radikal bebas secara optimal.
Kelompok P2 dengan dosis MSG $0,7 \mathrm{mg} / \mathrm{gBB}$ dan dosis ekstrak etanol brokoli $1000 \mathrm{mg} / \mathrm{KgBB}$ tikus di dapatkan rerata 42,68 Unit/ $\mu$ l. Jika dibandingkan antara kelompok $\mathrm{K}_{+}$ terjadi kenaikan kadar SOD secara signifikan $(\rho=0,000)$ dan jika kelompok K- terjadi penurunan kadar SOD secara tidak bermakna $(\rho=0,506)$. Hal ini menunjukan bahwa pemberian $1000 \mathrm{mg} / \mathrm{KgBB}$ mampu meningkatkan kadar SOD ovarium tikus putih yang dipapar monosodium glutamat.

Kelompok P3 dengan dosis MSG 0,7 mg/gBB dan dosis ekstrak etanol brokoli (Brassica oleracea) $2000 \mathrm{mg} / \mathrm{KgBB}$ tikus di dapatkan

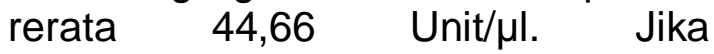
dibandingkan antara kelompok $\mathrm{K}+$ terjadi kenaikan kadar SOD secara bermakna $(\rho=0,000)$ namun jika kelompok K- terjadi penurunan kadar SOD secara tidak bermakna $(\rho=0,945)$. Hal ini menunjukan bahwa pemberian dosis $2000 \mathrm{mg} / \mathrm{KgBB}$ mampu meningkatkan kadar SOD ovarium tikus putih yang mendapat paparan monosodium glutamat.

Peningkatan kadar SOD dalam ovarium dapat terjadi karena kandungan antioksidan dalam brokoli. Brokoli memiliki manfaat sebagai antioksidan karena kandungan air, serat, protein, kalsium, zat besi, Vitamin A dan C, B16, B17, glutamin, asam amino, dan anti inflamasi(19). Brokoli mengandung beberapa senyawa fenolik, salah satunya adalah flavonoid. Flavonoid merupakan sumber antioksidan yang baik dalam menangkal radikal bebas, sehingga dapat mengurangi kerusakan oksidatif. Flavonoid memiliki aktivitas antioksidan yang tinggi dibandingkan dengan vitamin dan karotenoid(21). Beberapa penelitian menyebutkan bahwa brokoli dapat meningkatkan serum 
antioksidan, yaitu GSH, SOD pada tikus yang menderita diabetes ${ }^{(19)}$.

\section{SIMPULAN}

1. Monosodium glutamat (MSG) dapat menurunkan Kadar Superoxide dismutase (SOD) ovarium tikus putih (Rattus norvegicus).

2. Ekstrak etanol brokoli (Brassica oleracea) dapat meningkatkan kadar Superoxide dismutase (SOD) ovarium tikus putih (Rattus norvegicus) yang dipapar monosodium glutamat (MSG)

3. Dosis efektif ekstrak etanol brokoli (Brassica oleracea) dalam meningkatkan kadar Superoxide dismutase (SOD) ovarium tikus putih (Rattus norvegicus) adalah dosis ke-3 yaitu $2000 \mathrm{mg} / \mathrm{KgBB}$

4. Kenaikan dosis efektif ekstrak etanol brokoli (Brassica oleracea) diikuti dengan kenaikan kadar Superoxide dismutase (SOD) ovarium tikus putih (Rattus norvegicus) yang dipapar monosodium glutamat (MSG)

\section{DAFTAR PUSTAKA}

1. Kementerian perindustrian Republik Indonesia. 2016. Laporan Kerja Kementerian Perindustrian Tahun 2015. Biro perencanaan 2016, Jakarta, hal.

2. Walker, R and Lupien. 2000. Glutamate Safety In The Food Supply. American society For Nutritional Sciences.

3. Razali, Rezania. 2014. Monosodium Glutamat (MSG) dan Efek Neurotoksisitasnya Pada Sistem Saraf Pusat. Bagian Fisiologi Fakultas kedokteran Universitas Syiah Kuala, Banda Aceh.

4. Yueniwati, Yuyun. 2015. Deteksi Dini Stroke Iskemia
Dengan Pemeriksaan Ultrasonografi Vaskular Dan Variasi Genetika. Malang: UB Press.

5. Onyema O., Ebenezer O., Godwin O., Agwu I., and Godffrey O. 2006. Effect Of Vitamin E On Monosodium Glutamate Induced Hepatotoxicity and Oxidative Stress In Rats. Indian Journal of Biochemistry \& Biophysics, 43: $20-24$.

6. Contini M., Nestor M., Luisina R., and Stela M. 2012. Kidney And Liver Functions and Stress Oxidative Markers of Monosodium GlutamateInduced Obese Rats. Food and Public Health. 2 (5): 168177.

7. Dhiru. 2013. Live Blood Analysis Setetes Darah Anda Dapat Mengungkapkan Status Kesehatan dan Penyakit yang Mengancam Anda. Jakarta: PT Gramedia Pustaka.

8. Septadina, Indri Seta. 2011. Perubahan Struktur Mikroskopis Ovarium Akibat Pemberian Monosodium Glutamat Pada Mencit (Mus Musculus) Betina Dewasa. MKS,43 (1):3129-3134.

9. Ramayulis, Rita., 2015. Green Smoothie Ala Rita Ramayulis: 100 Resep 20 Khasiat. Jakarta: Gramedia Pustaka Utama.

10. Dalimartha, Setiawan., 2000. Altlas Tumbuhan obat Indonesia. Jilid 2. Jakarta: Trubus Agriwidya. Prochazkova D., Bousova., and Wilhelmova. 2011. Antioxidant And Prooxidant properties Of Flavonoid: Review. ELSEVIER. 
11. Prochazkova D., Bousova., and Wilhelmova. 2011. Antioxidant And Prooxidant properties Of Flavonoid: Review. ELSEVIER

12. Shan Wang, Guolin He, Meng Chen, Tao Zuo, Wenming Xu and Xinghui Liu. 2017. The Role of Antioxidant Enxymes in the Ovaries. Oxidative Medicine and Cellular Longevity. 14(2017)

13. Nurhayati Siti, Teja Kisnanto, dan Mukh Syaifuddin. 2011. Superoksida

Dismutase (SOD): Apa Dan Bagaimana Peranannya Dalam Radioterapi. Buletin Alara. 13 (2): 67-74.

14. Cristiana, Filip, Albu Elena, and Zamosteanu Nina. 2014. Superoxide Dismutase: Therapeutic Targets in SOD Related Pathology. Scientific Research. 6: 975:988.

15. Farombi E.O and Onyema O.O. 2006. Monosodium Glutamate-Induceed Oxidative Damage and Genotoxicity in The Rat: Modulatory Role of Vitamin C, Vitamin E and Quercetin. Hum Exp Toxicol.25: 251-9.

16. Al-Harbi Muhammad, Nahla S and Najwa O. Effect Of Monosodium Glutamate On Oxidative Damage In Male Mince: Modulatory Role Of
Vitamn C. Advances in Food Sciences.36(4): 167-176.

17. Manisha, Whidul Hasan, Richa Rajak and Deepali Jat. 2017. Oxidative Stress and Antioxidants: An Overview. IJARR. 2 (9): 110-119.

18. Megawati, Dian, Sutarno dan Shanti Listyawati. 2005. Siklus Estrus dan Struktur Histologi Ovarium Tikus Putih (Rattus norvegicus) Setelah Pemberian Monosodium Glutamat (MSG) Secara Oral. BioSmart. 7(1): 47-52.

19. Khashan Mahdi Hamza, and Zainab Shnewer Mahdi AlTurfi. 2017. Effect of Alcoholic Extract of Brassica oleracea L.VAR Capita Plant Leaves On Glucose Level and Antioxidant Activity in Alloxaninduced Diabetic Rats. Scientific Journal of Medical Research. 1(1):19-23.

20. Simanjuntak, Kristina. 2012. Peran Antioksidan Flavonoid Dalam Meningkatkan kesehatan.Bina Widya, Vol 23 (3), 135-140, Fakultas Kedokteran UPN "Veteran", Jakarta.

21. Cartea Maria Elena, Marta Francisco, Pilar Soengas and Pablo Valasco. 2011. Phenolic Compounds in Brassica Vegetables. Molecules 16: 251-28 